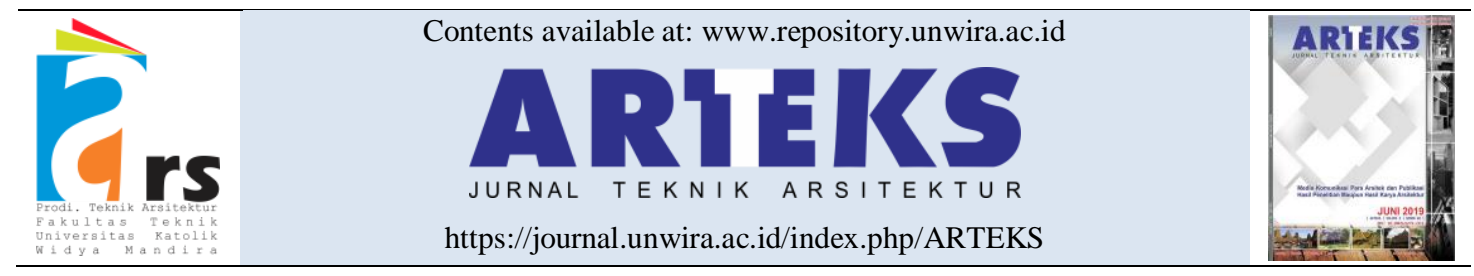

Research paper

doi: http://doi.org/10.30822/arteks.v5i2.405

\title{
Akulturasi religi dalam arsitektur vernakular rumah Melayu Pontianak
}

\author{
Muhammad Hidayat $^{1 *}$, Budi Prayitno², Dwita Hadi Ratmi ${ }^{3}$ \\ ${ }^{1}$ Jurusan Teknik Arsitektur, Politeknik Negeri Pontianak \\ Jl. Ahmad Yani, Pontianak, Indonesia \\ ${ }^{2,3}$ Departemen Teknik Arsitektur dan Perencanaan, Fakultas Teknik, Universitas Gadjah \\ Mada, Jl. Grafika, no. 2, Kabupaten Sleman, Yogyakarta - 55284, Indonesia
}

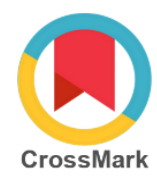

\begin{tabular}{l}
\hline ARTICLE INFO \\
\hline Article history: \\
Received March 01, 2020 \\
Received in revised form March 20, \\
2020 \\
Accepted April 18, 2020 \\
Available online August 01, 2020
\end{tabular}

Keywords:
Acculturation
Architectural vernacular
Immanence
Islam
Pontianak Malay house

ABSTRACT

Religious acculturation in vernacular architecture in the Pontianak Malay house

Since its founding, Pontianak has been a multicultural society which is, reflected by the embodiment of the acculturation of traditional house architecture found in the neighborhoods where the city was firstly established and still exist until today. The history this city shows, that multicultural has existed for a long time, as the result of cultural integration of certain ethnic groups in the early formation of the Pontianak sultanate. This research is intended to explore further, the religious acculturation that accompanies the embodiment of ethnic acculturation in the vernacular architecture of the Pontianak Malay house. In this city, Malay is an embodiment of inter-ethnic diaspora who share Islamic faith. This research is a qualitative-descriptive research with a case study approach that involve 30 selected samples. The analysis is based on the extent to which the strength of the religious system of each ethnicity involved

*Corresponding author: Muhammad Hidayat in the process of acculturation, with reference to the history of the development of da'wah in Pontianak in particular and in West Kalimantan in general. The study uncovered that religious acculturation embodied in Pontianak Malay vernacular architecture represented the form of tolerance between Islamic religious groups of each ethnicity (acculturation-separative) and in the physical element of acculturation to show respects to the authority of the Bugeinese vernacular (integrative-assimilative acculturation). It is hoped that the results of this study will further enrich the main elements of the vernacular architecture of the Pontianak Malay house, and will further illustrate the richness of Pontianak Malay Culture.

\section{Pendahuluan}

Kota Pontianak sering dikenal sebagai kota katulistiwa, karena posisi geografisnya yang dilintasi garis katulistiwa (equator_00) (BAPPEDA Kota Pontianak 2018). Kekhasan yang belum banyak dipahami adalah bahwa Kota Pontianak sejak awal berdiri merupakan kota multietnik, semua etnik memiliki peran dalam pembentukan perkembangan Kota Pontianak. Semua etinik adalah para pendatang/migran yang datang ke Pontianak, berinteraksi dan berakulturasi, sehingga terjadi diaspora Melayu Pontianak (Hasanuddin and Kristanto 2001).

Sebutan Melayu Pontianak merupakan titik kompromi sebagai "rumah bersama" bagi 
beragam etnik yang ada, khususnya etnik yang memiliki kesamaan dalam keyakinan iman Islam. Sehingga, budaya Melayu Pontianak pada hakikatnya adalah produk akulturasi religiusitas Islam dari beragam migran etnik yang datang sejak awal ataupun yang datang kemudian di wilayah Pontianak.

Dalam lingkup arsitektur, akulturasi yang terjadi adalah akulturasi bentuk yang mewujud pada elemen-elemen bangunan (Lalu and Fauzy 2020), dalam konteks bahasan pada artikel ini adalah rumah tinggal, sebagai cara berkompromi dari masing-masing migran etnik yang berinteraksi secara budaya. Akulturasi bentuk tersebut menghasilkan karakter bangunan yang khas, yang menandai perwujudan arsitektur rumah Melayu Pontianak (Salura and Fauzy 2012; Salura and Fecianti 2015; Sukada and Salura 2020; Salura 2012).

Dialektika budaya bentuk yang terjadi adalah dialektika budaya teknologi yang disepakati dan dijalani oleh semua etnik yang berinteraksi dan berakulturasi, dan membentuk cara membangun atau budaya membangun dalam masyarakat multietnik tersebut (Adimihardja and Salura 2004). Atau dalam terminologi arsitektur, akulturasi bentuk terjadi pada elemen arsitektur vernakular, yang disepakati masyarakat setempat sebagai cara membangun dan membentuk arsitektur rumah tinggal setempat (Wiranto 1999; Salura and Fauzy 2013).

Tema akulturasi religi yang diangkat dalam penelitian ini karena memiliki keterkaitan langsung dengan kejadian akulturasi etnik yang mewujud dalam elemen arsitektur vernakular rumah Melayu Pontianak. Masing-masing etnik saling berinteraksi dan berakulturasi tidak hanya dalam membangun tatanan vernakularitas bangunan rumah, tapi juga melibatkan aspek religi dan atau kosmologi yang melekat pada elemen bangunan rumah yang menjadi keyakinan dari masing-masing etnik. Dalam penelitian ini diambil 30 situs rumah vernakular yang saat ini masih lestari dan dibangun sejak awal berdirinya Kraton Kesultanan Kadriah dan Masjid Jami' pada tahun 1778 Masehi yakni pada masa Sultan I Sy. Abdurrahman Al-Kadrie, hingga kesultanan terakhir pada masa Sultan VI Sy. Muhammad AlKadrie pada tahun 1945 (Hidayat, Prayitno, and Rahmi 2020) (Lihat gambar 1).

Menurut Hidayat (2020) dari penelusuran sejarah migrasi penduduk ke Pontianak, terdapat empat etnik utama yang berinteraksi dan berakulturasi di masa-masa awal dalam mendukung Sultan I membangun keraton Kesultanan Kadriah Pontianak dan membangun permukimannya. Keempat etnik tersebut; etnik Arab (Sultan), etnik Bugis, etnik Riau, dan etnik Banjar (Hidayat, Prayitno, and Rahmi 2020).

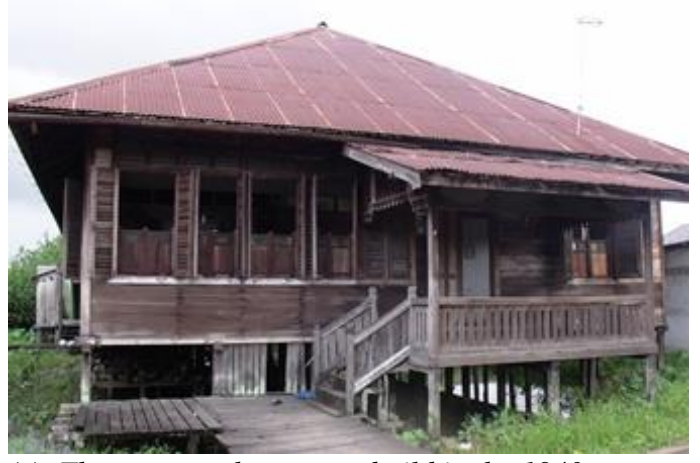

(a) The youngest house was build in the 1940s

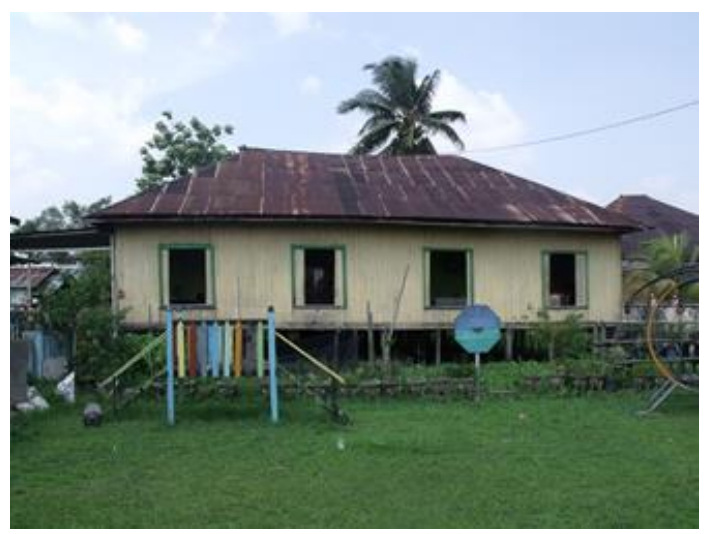

(b) The oldest house was build in the 1800s

Gambar 1. Orientasi religi dalam kosmologi masingmasing etnik

Keempat kelompok etnik tersebut secara spesifik berakulturasi secara integratif-asimilatif, dimana kemudahan berakulturasi karena ada kesamaan yang mengikat (binding similarity). Yang utama adalah faktor sosio-religi mereka yang memiliki kesamaan keyakinan iman-Islam hingga memikili enkulturasi yang sama (mutual intension) yang menjadikan kelompok etnik mudah dalam proses berakulturasi (Hidayat, Prayitno, and Rahmi 2020).

Permasalahan yang muncul dalam penelitian ini adalah dialektika religi yang terjadi antar etnik yang berakulturasi terkait dengan rumah tinggal kelompok etnik. Karena terdapat polarisasi dalam religiusitas masing-masing etnik, di satu sisi ada yang meyakini Islam secara murni/asli, sehingga dinamikanya akulturasinya lebih pada dinamika 
purifikasi. Di sisi lain ada yang meyakini Islam secara sinkretis, yakni keyakinan Islam yang tercampur dengan keyakinan lama (animismdynamism). Pada gambar 2 di bawah ini menunjukkan tiap migran etnik di pontianak memiiki orientasi religiusitas Islam yang berbeda

Arab

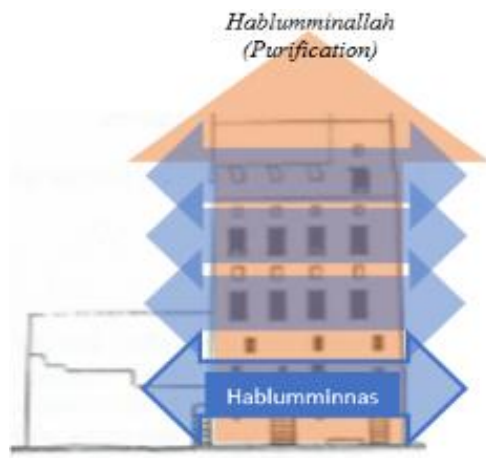

Bugis

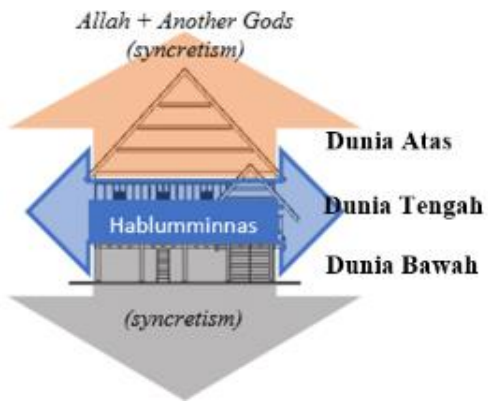

Riau

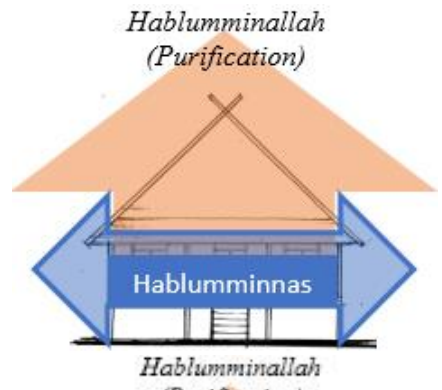

Banjar

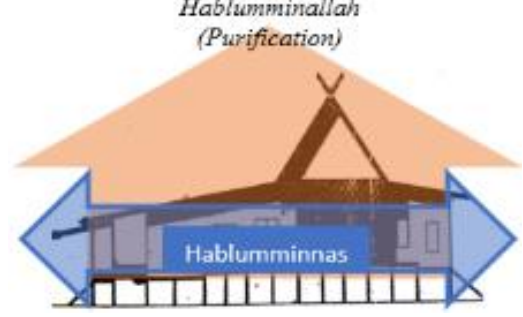

dalam aspek kosmologi masyarakat komunitanya. Sehingga saat komunitas etnik tersebut berinteraksi dan berakulturasi di Pontianak, mereka tidak hanya melakukannya dalam aspek elemen bentuk (vernakular) tapi juga mengkomrpomikan aspek keyakinan (religiosity).

Religiusitas Islam yang masih asli (dakwah/purifikasi)

Religiusitas sinkretisme Islam (campuran animism/dinamisme

Religiusitas Islam - tradisi (purifikasi tradisi)

Religiusitas Islam - tradisi (purifikasi tradisi

Gambar 2. Orientasi religi dalam kosmologi masing-masing etnik

Gambar 2 tentang orientasi religi dalam kosmologi masing-masing etnik menunjukkan posisi religiusitas etnik Bugis sangat kental syncretisism, sedangkan religiusitas etnik Riau dan etnik Banjar memiliki akulturasi di tingkatan tradisi, beberapa hal masih bersinggungan dengan aspek keyakinan (aqidah) yang masih diperdebatkan hingga sekarang. Tapi komunitas etnik tersebut relatif telah mengalami proses purifikasi (sibghotullah), dan merasa tidak 
melakukan kesyirikan (penyekutuan Tuhan) dalam upaya melestarikan tradisi lama. Etnik Arab, apalagi Arab Alawiyyin, memiliki beban sejarah yang harus dijaga sebagai ahlul Bait, sehingga dituntut juga menjaga purifikasi Islam secara benar dan konsisten.

Pertayaan penelitiannya ialah bagaimana dan mengapa dialektika budaya bentuk yang dikompromikan menyangkut elemen vernakular bangunan di satu sisi dan orientasi religiusitas Islam yang berbeda pada sisi yang lain.

Tujuan dari penelitian ini adalah pertama, menemukan wujud dialektika dalam akulturasi religi yang melekat dalam elemen arsitektur vernakular rumah Melayu Pontianak. Kedua, menemukan gambaran purifikasi Islam (murni) yang berhadapan religiusitas Islam yang berbeda, terkait dengan jaringan ulama yang sudah ada pada waktu akulturasi terjadi.

\section{Metode penelitian}

Menurut Koentjaraningrat bahwa unsur religi merupakan unsur kebudayaan yang sulit berubah, sementara unsur teknologi/peralatan merupakan unsur budaya yang paling mudah berubah (Koentjaraningrat 1993; Sutrisno 1990). Dalam penelitain ini, kedua unsur di atas merupakan unsur yang bisa ditemui datanya di lapangan. Oleh karenanya, penelitian ini akan mengaitkan dua hal; (1) unsur fisik arsitektur rumah tua Pontianak sebagai unsur teknologi yang masih berdiri artefaknya hingga saat ini. (2) religiusitas etnik melayu Pontianak, sebagai hasil akulturasi religi yang kemungkinan masih bisa ditelusuri dalam keyakinan di masyarakat.

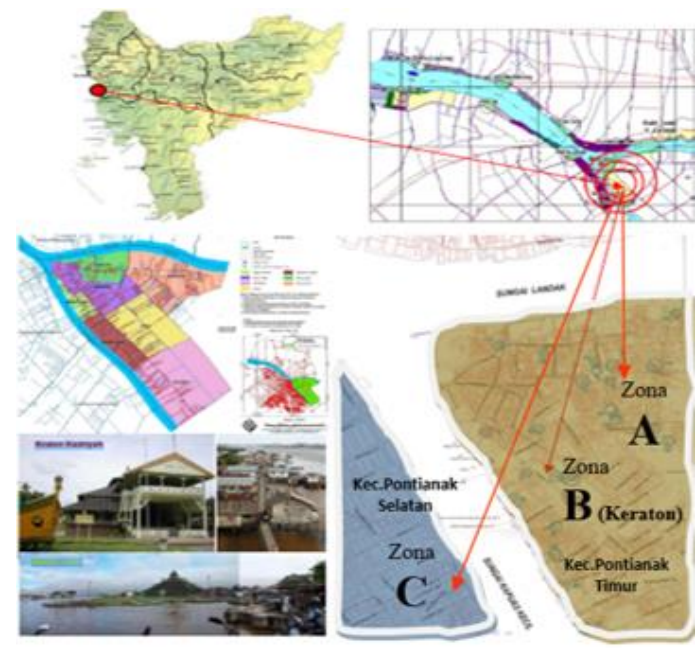

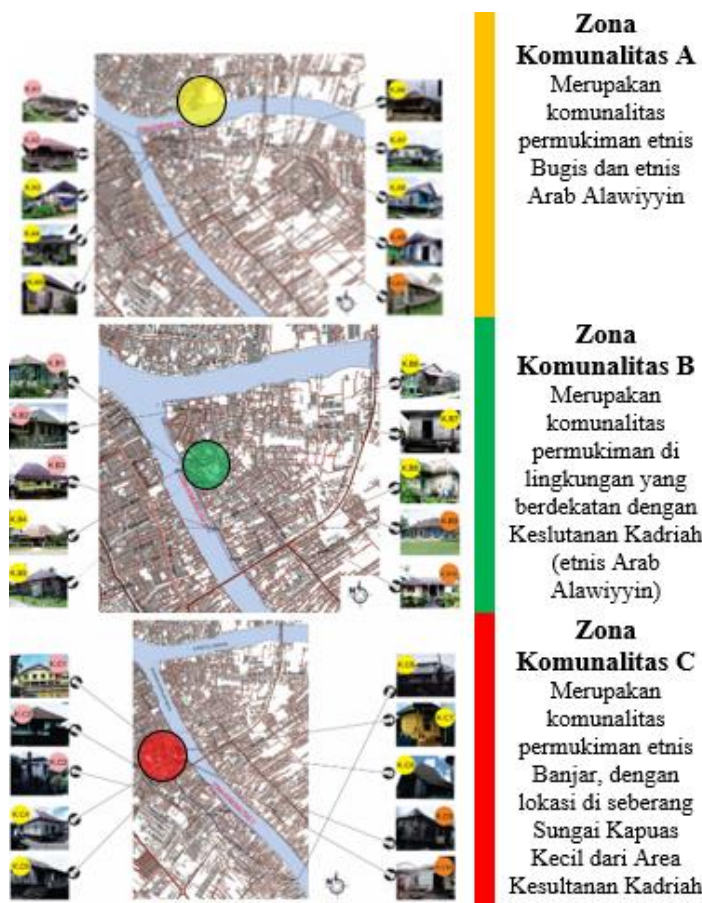

Gambar 3. Lokasi 30 kasus rumah tua di Pontianak dalam 3 zona komunalitas etnik (Hidayat, Prayitno, and Rahmi 2020)

Dengan mengunakan data penelitian sebelumnya, terdapat 30 kasus rumah tua di Pontianak dalam 3 komunalitas berbeda (Lihat gambar 3). Dibangun antara \pm 80 tahun sampai 200 tahun yang lalu, dikaji hubungan antara hasil akulturasi elemen arsitektur dengan akulturasi religi, ditengah karakter dasar aqidah Islam yang bersifat purifikatif di Kalimantan Barat.

Untuk data fisik rumah (unsur teknologi/alat) akan dilakukan kajian secara nomotetik untuk temuan yang sifatnya kuasi-kualitatif. Sedangkan, untuk data kualitatif terkait dengan unsur religi akan dilakukan secara ideografik, melalui wawancara dan kajian literatur terkait.

Penelitian ini merupakan penelitian dengan metode studi kasus, yakni mambangun sintesa antara fakta dan teori (Synthesizing of cases). Pendekatan metode ini merujuk pada salah satu model generalisasi metode studi kasus yang disampaikan oleh Rolf Johansson (Johansson 2003). Sehingga, temuan akulturasi religi dibangun dari uji pembandingan atas kasus-kasus yang mengemuka di lapangan ditinjau dari peran masing-masing etnik yang berakulturasi. Dan dari semua itu dilakukan kesimpulan (inferensi) sebagai bentuk konstruksi hasil penelitian. 


\section{Temuan dan pembahasan}

Merujuk pada hasil temuan penelitian sebelumnya, Hidayat mengemukan adanya tiga kondisi yang mewujud dan mengelompok dalam tiga keadaan berbeda, yaitu: (1) elemen-elemen yang bertahan (continuity elements); (2) elemenelemen yang mudah berubah (changeable elements); dan (3) elemen -elemen yang mengikat (bonding elements) (Hidayat, Prayitno, and Rahmi 2020).
Dalam temuannya itu Hidayat menyampaikan bahwa seperti yang terlihat pada tabel 1 di bawah ini, ternyata elemen-elemen yang bertahan (continuity elements) pada arsitektur vernakular rumah tua Pontianak, merupakan elemen-elemen inti (core elemens) yang saling terhubung erat hingga mampu terbentuk model konstruksi bangunan rumah tinggal. Implikasinya menjadi indikasi bahwa akulturasi elemen bentuk secara fisik mengarah pada perwujudan arsitektur vernakular rumah Melayu Pontianak.

Tabel 1. Elemen yang dominan, menggambarkan vernakularitas yang bertahan dalam 150 tahun

\begin{tabular}{|c|c|c|c|c|c|c|c|c|c|}
\hline \multirow{2}{*}{ No } & \multirow{2}{*}{ Elemen } & \multirow{2}{*}{$\begin{array}{l}\text { Distribusi } \\
\text { Data } \\
\text { Karakter }\end{array}$} & \multicolumn{2}{|c|}{$\begin{array}{c}\text { Indikasi } \\
\text { Vernakular } \\
\text { Pontianak }\end{array}$} & \multicolumn{4}{|c|}{$\begin{array}{l}\text { Etnik yang Lebih Dominan } \\
\text { Mempengaruhi Bentuk }\end{array}$} & \multirow{2}{*}{$\begin{array}{c}\text { Perwujudan Temuan } \\
\text { Akulturasi }\end{array}$} \\
\hline & & & $\begin{array}{l}\text { Karakter } \\
\text { Dominan }\end{array}$ & (\%) & Arab & Bugis & Riau & Banjar & \\
\hline 1 & $\begin{array}{c}\text { Plan } \\
\text { (spatial) }\end{array}$ & & $\begin{array}{c}\text { Grid } \\
\text { (Lontang) }\end{array}$ & 93 & -- & $\sqrt{ }$ & - & - & $\begin{array}{l}\text { Bentuk kerangka modul grid } \\
\text { pembentuk denah sepenuhnya } \\
\text { konsep Lontang dalam rumah } \\
\text { vernakular Bugis. }\end{array}$ \\
\hline 2 & $\begin{array}{c}\text { Roof } \\
\text { (physical) }\end{array}$ & & Limas & 87 & - & $\sqrt{ }$ & - & $\sqrt{ }$ & $\begin{array}{l}\text { Bentuk Limas muncul sebagai } \\
\text { preseden baru sebagai } \\
\text { transformasi /integrasi wujud } \\
\text { orientasi atap antara vernakular } \\
\text { Bugis dan vernakular Banjar }\end{array}$ \\
\hline 3 & $\begin{array}{r}\text { Space of } \\
\text { Roof/Plafo } \\
\text { nd (spatial) }\end{array}$ & & Plafond & 77 & - & $\sqrt{ }$ & -- & - & $\begin{array}{l}\text { Vernakular Bugis mensyaratkan } \\
\text { ruang bawah atap, bagi semua } \\
\text { rumah yang dibangunnya, sebagai } \\
\text { gambaran keyakinan mereka } \\
\text { tentang konsep Rakkeang (dunia } \\
\text { atas) dalam kosmologi Bugis. }\end{array}$ \\
\hline 4 & $\begin{array}{c}\text { Floor } \\
\text { Height } \\
\text { (physical) }\end{array}$ & & $\begin{array}{l}\text { Lantai } \\
\text { Datar } \\
\text { (tidak ada } \\
\text { hirarkhi) }\end{array}$ & 100 & - & $\sqrt{ }$ & $\sqrt{ }$ & -- & $\begin{array}{l}\text { Semua etnik sepakat untuk tidak } \\
\text { membuat pembedaan lantai dalam } \\
\text { rumah Induk (sebagai wujud prinsip } \\
\text { kesamaan) }\end{array}$ \\
\hline 5 & $\begin{array}{l}\text { Fondation } \\
\text { (physical) }\end{array}$ & & $\begin{array}{l}\text { Alas-Laci } \\
\text { Galang }\end{array}$ & 100 & - & $\sqrt{ }$ & -- & $\sqrt{ }$ & $\begin{array}{c}\text { Bentuk rekayasa baru wujud baru } \\
\text { sistem Pondasi, sebagai } \\
\text { transformasi/integrasi dari sistem } \\
\text { Kacapuri Banjar dengan konsep } \\
\text { sistem Stake Bugis. }\end{array}$ \\
\hline 7 & $\begin{array}{c}\text { Main } \\
\text { Column } \\
\text { (physical) }\end{array}$ & & $\begin{array}{l}\text { Kolom } \\
\text { Utama } \\
\text { ('Pertama') }\end{array}$ & 100 & - & $\sqrt{ }$ & $\sqrt{ }$ & -- & $\begin{array}{c}\text { Semua etnis memiliki konsep yang } \\
\text { sama dalam proses ritual terhadap } \\
\text { satu Tiang Utama/Pertama (bernilai } \\
\text { seperti axis-mundi), seperti tiang } \\
\text { Aliri pada vernakular Bugis, namun } \\
\text { penyebutan "Tiang Seri" } \\
\text { merupakan istilah dari vernakular } \\
\text { Riau } \\
\end{array}$ \\
\hline
\end{tabular}

(Hidayat, Prayitno, and Rahmi 2020) 
Dari elemen-elemen inti di atas dapat dibuat ilustrasi model (Lihat gambar 4) yang membentuk arsitektur vernakular rumah Melayu Pontianak.

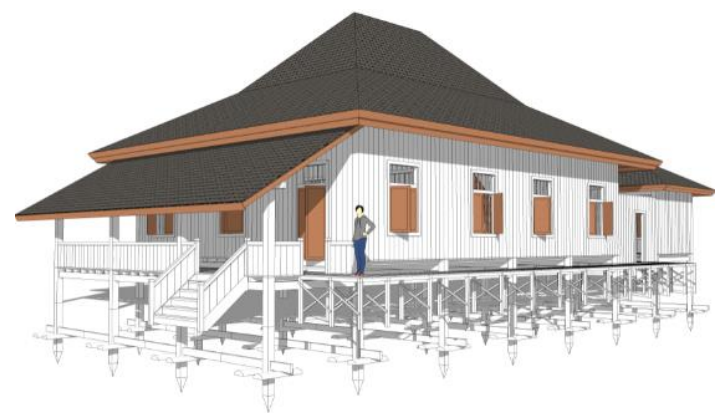

Gambar 4. Model perwujudan akulturasi etnik pada elemen arsitektur vernakular rumah Melayu Pontianak (Hidayat, Prayitno, and Rahmi 2020)

Hidayat menyatakan bahwa data telah menunjukkan adanya dominasi vernakular Bugis dalam akulturasi etnik pada elemen arsiektur vernkular rumah Melayu Pontianak. Ini juga sekaligus menggambarkan tentang aspek pertukangan yang telah terlembaga dengan baik dan bertahan selama 150 tahun. Adalah suatu bentuk kepintaran lokal (the local genious) yang banyak tersusun dari unsur vernakularitas arsitektur rumah tinggal etnik Bugis.

Dalam tabel 1 di atas, Hidayat mengemukakan bahwa pada semua elemen utama/core seperti; unsur konsep denah, bentuk atap, ruang bawah atap, perbedaan tinggi lantai, sistem pondasi, hingga kedudukan tiang utama ("axis mundi") mencerminkan unsur utama bangunan. Dan semua angka berada di atas $75 \%$ (dominan) dan mengarah pada peran vernakular etnik Bugis (Hidayat, Prayitno, and Rahmi 2020).

Terkait dengan akulturasi religi, dialektika religiusitas etnik Bugsi yang merupakan religiusitas sinkretisme Islam memiliki peluang yang dominan berhadapan dengan purifikasi Islam (etnik Arab) dan purifikasi Islam tradisi (etnik Riau, etnik Banjar).

Dari data yang ada terkait dengan hasil akulturasi elemen vernakular rumah Melayu Pontianak dan hasil akulturasi religi yang melekat pada elemen tersebut menggambarkan beberapa temuan menarik. Karena tidak setiap elemen memiliki lekatan nilai religi didalamnya, hanya elemen-elemen tertentu.

Sehingga beberapa temuan penting dan penjelasannya dapat diuraikan sebagai berikut: (1) Terdapat elemen yang menunjuk kan indikasi kuat tentang adanya akulturasi religi yang bersifat asimilatif dalam hal bentuk dan keberadaan ruang bawah atap. Tergambar pada semua sampel kasus rumah tua di Pontianak (100\%), semua etnis menerima keberadaan ruang bawah atap Bugis. Yang membedakan hanya kebaradaan tangga ke atas $(77 \%)$ yang diartikan bahwa ruang itu akan difungsikan untuk ritual tertentu, dan (33\%) tidak membuat tangga/sebatas plafond penutup. Keberadaan ruang atap menunjukkan tentang kuatnya sistem religi (hierarki kosmologis) dari vernakular Bugis pada masa itu, yang diwakili oleh kelompok pertukangan etnik Bugis dalam mengerjakan pembangunan rumah-rumah setiap etnik yang ada di Pontianak. Kondisi ini melembaga sedemikian rupa, sehingga mampu bertahan dan berumur hingga sampai bangunan terakhir (termuda) yang didirikan sekitar tahun 1940-an. Apakah pelembagaan vernakular ini karena aspek kosmologi di atas? masih perlu diuji lebih lanjut mengingat kondisi tersebut, karena faktor modalitas pertukangan Bugis. Sedangkan, perkembangan pada awal abad 20 sudah banyak kelompok pertukangan China (Wati 1989), dan masih mempertahankan cara etnis Bugis membangunnya, dimana pertukangan China melakukan adopsi cara membangun rumah oleh etnis Bugis bukan karena pandangan kosmologisnya, karena nilai warisannya yang sudah melembaga di masyarakat. Kenapa semua etnik menerima bentuk ini (assimilative strategy)? dugaan utama adalah karena hal itu terkait dengan keyakinan para pertukangan etnis Bugis harus membuat keberadaan 3 dunia tetap harus dibangun sebagai bagian dari pandangan kosmologinya, seperti yang terlihat pada gambar 5.

Perkembangan morfologi ruang selanjutnya adalah sumur, tempat wudu, dan kamar mandi/toilet. Sumur dibangun di sebelah Utara Masjid pada tahun 1970 dengan fungsi sebagai tempat untuk berwudu. Posisi sumur berada di dalam kuadran IV sejak 1970 hingga 1990 (Lihat gambar 5). Kamar mandi/toilet dan tempat wudu dibangun pada tahun 1980 dan secara konsisten menempati kuadran IV hingga tahun 2019. Secara morfologinya kedua ruang ini memiliki perkembangan yang sangat signifikan dimulai pada tahun 2005 dengan menggabungkan kedua ruang tersebut dan membaginya berdasarkan jender, yakni pria di Selatan dan wanita di Utara. Pada tahun 2010 terdapat penambahan ruang kamar mandi/toilet dan tempat wudu yang dibangun di sebelah Timur terpisah dari bangunan Masjid. Ruang ini kemudian menjadi tempat 
wudu serta kamar mandi/toilet bagi wanita (Lihat gambar 5).

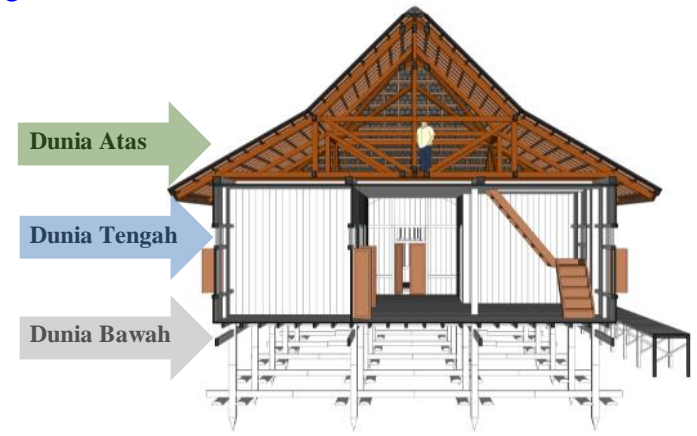

Gambar 5. Keberadaan ruang bawah atap yang menandai kuatnya kosmologi arsitektur vernakular etnik Bugis (Hidayat, Prayitno, and Rahmi 2020)

Walau entik lain (Arab, Banjar, Riau) menerima keberadaan ruang atap, tapi secara kosmologis etnik tersebut tidak memiliki keyakinan itu, sehingga cenderung sikapnya dengan tidak dibuat tangga ke atas, atau tidak digunakan sama sekali ruangnya. Sedangkan, untuk etnik Bugis menggunakannya sesuai dengan keyakinannya yakni untuk hal-hal yang sifatnya suci (eden) atau sesaji-sesaji bagi "Yang Menguasai Dunia Atas"; (2) Keberadaan tiang 'seri' ('axis mundi') pada rumah tua di Pontianak, yang keberadaaan diyakini oleh masyarakat pemiliki rumah memiliki kekuatan menjaga rumah dari hal-hal buruk yang tidak diinginkan (Lihat gambar 6). Keyakinan ini persis seperti yang diyakini oleh etnik Bugis dengan tiang alirinya sebagai sumbu dunianya. Baik tiang seri maupun tiang aliri keduanya disakralkan dan oleh karenanya saat memulai pendirian bangunan, pada tiang tersebut dilakukan upacara dan doa tertentu yang dipanjatkan, sebelum dibangun secara keseluruhan. Penyebutan "seri" adalah sebutan tiang utama pada etnik Riau (tiang seri), perbedaannya tiang utama tiang seri etnik Riau berjumlah 5 batang tiang yang diupacarakan;

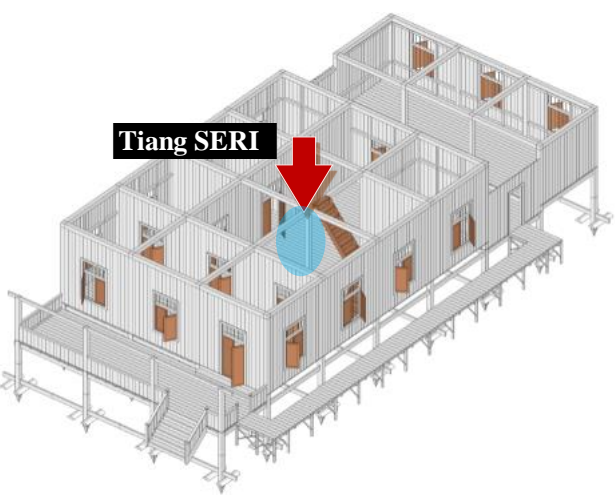

Gambar 6. Keberadaan tiang seri pada arsitektur vernakular rumah Melayu Pontianak (Hidayat, Prayitno, and Rahmi 2020)

(3) Untuk etnik Arab Alawiyyin, menganut satudua amalan Thariqah (Tariqah Haddad Alwy dan Tariqah Qadiriyyah Naqsha-bandiyah). Etnik Arab Alawiyyin menggunakan satu atau dua ruang untuk digunakan sebagai ruang berdzikir dan melafadzkan seluruh amalan dzikirnya. Seperti terlihat pada gambar 7, pertama, menggunakan ruang kamar depan yang paling Barat (dekat kiblat) untuk dijadikan ruang 'khalwat' (bermunajat) untuk menyendiri dan tidak terganggu dalam aktifitas dzikirnya.

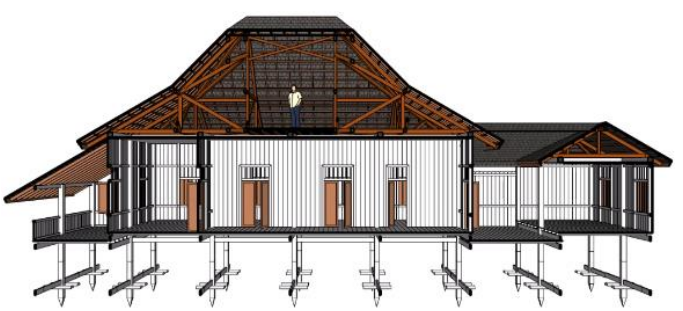

Gambar 5. Keberadaan kamar depan dan ruang perantara untuk aktifitas dzikir thariqah etnik Arab Alawiyyin (Hidayat, Prayitno, and Rahmi 2020)

Kedua, menggunakan ruang pelantaran (inner court) juga untuk melakukan aktifitas dzikirnya pada malam hari dan langsung berhadapan dengan langit (tidak terhalang atap).

Kembali pada tujuan pertama dari penelitian ini, bahwa sejauhmana akulturasi religi terjadi dalam akulturasi etnik elemen arsitektur vernakular rumah tua (Melayu) Pontianak. Keempat temuan di atas menunjukkan bahwa keempat etnik yang berakulturasi tersebut, membawa nilai religiusitas masing-masing yang juga merupakan produk akulturasi dengan para ulama pendakwah sebelumnya yang hadir dalam setiap komunitas etnik, serta menghasilkan nilai religiusitas Islam yang memiliki perbedaan. 
Melalui kegiatan observasi, studi literatur dan wawancara mendalam dengan berbagai sumber kunci (key informan), beberapa hal dapat diposisikan sebagai berikut: Bahwa karakter dakwah Islam yang dipraktekkan Nabi Muhammad Shallallahu 'alaihi wasallam (Saw) adalah memurnikan aqidah (purification), dimana pada era Makkah (13 tahun) adalah menanamkan dasar aqidah tidak langsung berhasil, dan pada era Madinah (10 tahun) kekuatan purifikasi aqidah mampu membangun peradaban Islam dengan syariah yang dicontohkan langsung dari Nabi Saw. Di tahun menjelang akhir kenabian, penaklukan Makkah merupakan puncak proses purifikasi Nabi Saw, dengan menghancurkan segala kesyirikan (penghancuran 365 berhala/kesyirikan), dan mengajak penduduk Makkah untuk memurnikan Aqidah. Akhirnya, dengan bukti nyata adanya penghidupan dan peradaban Madinah yang sempurna dalam ketauhidan yang lurus, Makkah berhasil melakukan purifikasi tanpa konflik, sebagai wujud bagaimana proses semangat purifikasi dalam aqidah, persuasi dalam muamalah, dan akhlaq Ikhsan dalam membangun budaya. Dan tiga dimensi gerakan dakwah di atas terus melembaga hingga kejayaan Islam pada abadabad sesudahnya.

Gerakan dakwah Islam di Nusantara berkembang sedemikian rupa hingga tergambar bagaimana jaringan Ulama Nusantara terjalin selama berabad-abad (Naim 2017). Dan suatu keniscayaan bahwa purifikasi aqidah merupakan dasar perubahan kondisi umat Islam di wilayah Nusantara. Kalimantan termasuk memiliki jaringan Ulama besar yang semestinya berpengaruh pada perjalanan peradaban umat Islam di wilayah Kalimantan. Ulama besar seperti Syaikh Arsyad al-Banjari (1710-1812), Syaikh Ahmad Khatib As-Sambasi (1802-1879), Syaikh Muhammad Basuni Imran (1885-1953) dan Guru Haji Ismail Mundu (1870-1960), merupakan persambungan Ulama besar yang bersentuhan langsung dengan kesultanan di Banjarmasin, di Sambas, di Mempawah, di Kubu dan yang paling muda di kesultanan Pontianak (Rahmadi 2010). Seperti Guru Haji Ismail Mundu merupakan Mufti Kesultanan Kubu dan juga Kesultanan Pontianak. Silsilah ini menunjukkan bahwa kasus Pontianak diyakini sangat dekat dengan proses purifikasi aqidah dalam perjalanan peradaban Kota Pontianak.

Namun, data wawancara dengan tokoh-tokoh kunci di lapangan menunjukkan adanya fakta bahwa, hingga awal-awal abad 20 tidak terjadi akulturasi religi secara esensial, bahkan purifikasi dakwah Islam dapat dinilai belum berhasil mengubah religiusitas Islam lama yang masih diyakini oleh masing-masing etnis (sinkretis dan atau tradisionis) (Depari 2012).

Dari data wawacara dengan tokoh kunci dan kajian literatur, menunjukkan bahwa sampai akhir abad 19 dan awal abad 20 tidak terjadi akulturasi religi dalam pengertian purifikasi aqidah terhadap religiusitas etnik Bugis, akulturasi religi terjadi dalam bentuk separasi (separation strategy), saling menghormati dan bertoleransi terhadap religiusitas masing-masing (Berry 1997).

Pada konteks arsitektur vernakular rumah tinggal, etnik lain (Arab, Banjar dan Riau) terhadap etnik Bugis cenderung melakukan pembiaran (assimilation strategy), atas rumahnya yang dibangun dalam rancangan rakkeang (dunia atas), ale bola (dunia tengah) dan awa bola (dunia bawah). Yang penting secara kosmologis, etnik tersebut tidak mengakui keberadaan paham sikretisme seperti itu. Kejadian ini seperti juga yang dialami para Walisongo di Jawa, yang tidak sepenuhnya berhasil (selesai) melakukan purifikasi Islam dan masih menjadi tanggung jawab ulama-ulama sesudahnya (Alexandrin 2010).

Gerakan besar yang hadir di awal abad 20 seperti gerakan Nahdlatul 'Ulama (NU) dan gerakan Muhammadiyah, ternyata di lapangan dapat dinilai lebih berhasil dalam proses purifikasi Islam dibanding sebelum komunitas etnik hadir. Melalui pengembangan lembaga pendidikan Muhammadiyah maupun pengembangan pesantren Nahdlatul 'Ulama (NU) di wilayah Kalimantan Barat.

\section{Kesimpulan}

Dari hasil analisis dan pembahasan, dapat ditarik kesimpulan terkait dengan perwujudan akulturasi religi dalam akulturasi elemen arsitektur vernakular rumah Melayu Pontianak.

Akulturasi religi merupakan titik pertemuan religiusitas Islam antar etnik yang berakulturasi. Sejarah dakwah dari Nabi Saw hingga akhir jaman, merupakan upaya purifikasi aqidah, sehingga manusia terbebas dari belenggu sinkretisme karena adanya keterancaman yang tidak pernah jelas sebabnya. Namun, dalam perkembangan dakwah Islam, seperti di wilayah 
Nusantara, religiusitas Islam yang ada pada setiap etnik itu merupakan hasil akulturasi religi pada proses sebelumnya yang membawanya pada kondisi polarisasi antara purifikasi Islam dan sinkretisme islam.

Hingga menjelang abad 20, proses Akulturasi religi, religiusitas dari semua etnik cenderung mengambil strategi memisahkan diri atau separasi (separation strategy) untuk menghormati keyakinan etnik lain sehingga tidak membawa mereka pada konflik etnik.

Akulturasi pada elemen fisik, etnik lain cenderung mengambil strategi asimilasi atau integrasi (assimilation and integrasion strategy), sehingga menerima atau kompromi terhadap elemen fisik arsitektur yang akan diberikan/dibangunkan, bergantung dari modalitas dari masing-masing etnik yang berakulturasi. Dalam kasus ini, aspek vernakular arsitektur etnik Bugis yang diwakili oleh modalitas pertukangan etnik Bugis, ditemukan bahwa sikap etnik untuk aspek yang memiliki modalitas rendah (skill and knowledge) cenderung mengikuti apa yang terbaik menurut etnik Bugis (assimilation strategy), dan akan bersikap kompromi (integrasion strategy) bila memiliki modalitas yang lebih baik.

Proses berkompromi apapun strategi berakulturasi yang dipilih dalam perwujudan akulturasi elemen arsitektur vernakular, tidak mengganggu tingkat independensi dari religiusitas Islam dari masing-masing etnik, dan tetap pada pandangan kosmologinya masingmasing. Dapat diartikan bahwa sepanjang ruang bawah atap sebagai (referent) dunia atas dan rakkeang sebagai (symbol) dunia atas, maka sepanjang etnik lain tidak memiliki (pikiran/thought atau reference) tentang dunia atas, maka adanya keyakinan kosmologi etnik Bugis tidak perlu dikhwatirkan.

\section{Ucapan terima kasih}

Artikel ini adalah bagian dari penelitian disertasi, di Universitas Gadjah Mada (Universitas Gadjah Mada) Yogyakarta. Untuk alasan itu, disampaikan terima kasih kepada semua yang mendukung penelitian ini. Ucapan terima kasih juga kepada informan atas informasi, data, dan waktu yang disediakan untuk penelitian ini. Terima kasih yang sebesar-besarnya kepada promotor dan ko-promotor yang telah memberikan bimbingannya sampai artikel penelitian selesai dibuat dan dipublikasikan pada ARTEKS : Jurnal Teknik Arsitektur.

\section{Referensi}

Adimihardja, Kusnaka, and Purnama Salura. 2004. Arsitektur Dalam Bingkai Kebudayaan. Edited by Anwar Holid. Bandung: Foris Publishing, CV. Architecture \& Communication.

Alexandrin, E. R. 2010. 'Cosmology and Architecture in Premodern Islam: An Architectural Reading of Mystical Ideas'. Comparative Studies of South Asia, Africa and the Middle East 30 (1): 153-55. https://doi.org/10.1215/1089201x-2009-064.

BAPPEDA Kota Pontianak. 2018. 'Kondisi Geografis Dan Demografi Pemerintah Kota Pontianak'. Berita Kota Pontianak. 2018. http://bappeda.pontianakkota.go.id/berita/kon disi-geografis-dan-demografi-pemerintahkota-pontianak-.

Berry, John W. 1997. 'Immigration, Acculturation, and Adaptation'. Applied Psychology $46 \quad$ (1): $\quad$ 5-34. https://doi.org/10.1111/j.14640597.1997.tb01087.x.

Depari, Catharina Dwi Astuti. 2012. 'Sebagai Produk Sinkretisme Budaya'. Jurnal Arsitektur KOMPOSISI 10 (1).

Hasanuddin, and Budi Kristanto. 2001. 'Proses Terbentuknya Heterogenitas Etnis Di Pontianak Pada Abad Ke-19'. HUMANIORA 13 (1): 64-81. https://doi.org/ttps://doi.org/10.22146/jh.712.

Hidayat, Muhammad, Budi Prayitno, and Dwita Hadi Rahmi. 2020. 'Mix Methods for Ethnic Acculturation Study on History of Architectural Elements: Vernacular Houses during Pontianak Sultanate'. ARSITEKTURA $18 \quad$ (1): 94. https://doi.org/10.20961/arst.v18i1.40488.

Johansson, Rolf. 2003. 'Case Study Methodology'. In Methodologies in Housing Research, 1-14. Stockholm: Royal Institute of Technology in cooperation with the International Association of People Environment Studies. http://www.psyking.net/HTMLobj- 
3839/Case_Study_Methodology-

_Rolf_Johansson_ver_2.pdf.

Koentjaraningrat. 1993. Manusia Dan Kebudayaan Di Indonesia. 14th ed. Jakarta: Djambatan.

Lalu, Efraim, and Bachtiar Fauzy. 2020. 'Dominasi Ragam Akulturasi Lokal-Moderen Pada Bangunan Casablancka Residence, Bali'. ARTEKS : Jurnal Teknik Arsitektur 5 (1): $67-74$. https://doi.org/10.30822/arteks.v5i1.187.

Naim, Ngainun. 2017. 'Abdurrahman Wahid: Universalisme Islam Dan Toleransi'. KALAM 10

423. https://doi.org/10.24042/klm.v10i2.8.

Rahmadi. 2010. 'Jaringan Intelektual Ulama Keturunan Syekh Muhammad Arsyad AlBanjari'. Al-Banjari : Jurnal Ilmiah Ilmu-Ilmu Keislaman 9 (2). https://doi.org/10.18592/albanjari.v9i2.927.

Salura, Purnama. 2012. 'Sintesis Elemen Arsitektur Lokal Dengan Non Lokal, Studi Kasus: Gedung Sate Di Bandung, Gedung UPS Di Tegal'. Bandung.

Salura, Purnama, and Bachtiar Fauzy. 2012. 'The Architectural Adaptation of Javanese Ethnic Houses to the Architectural Influence of Arab Ethnic Houses in Gresik'. Journal of Applied Environmental and Biological Sciences.

. 2013. 'Sintesis Elemen Arsitektur Lokal Dengan Non Lokal'. Bandung.

Salura, Purnama, and Fecianti. 2015. 'The Synthesis of Diagram Method and Local
Approach in Architectural Design'. International Journal of Academic Research 7 (3). https://doi.org/10.7813/20754124.2015/7-3.

Sukada, Nabila, and Purnama Salura. 2020. 'Basic Architectural Expression of a Cultural Center, Study Object: Volkstheater Sobokartti in Semarang, Indonesia'. ARTEKS: Jurnal Teknik Arsitektur 5 (1): 11-20. https://doi.org/10.30822/arteks.v5i1.76.

Sutrisno, Slamet. 1990. 'Unsur-Unsur Kebudayaan Sebagai Faktor Integritas Masyarakat Di Daerah Transmigrasi'. Jurnal Filsafat $1 \quad$ (1): 27-42. https://doi.org/https://doi.org/10.22146/jf.309 92.

Wati, Arena. 1989. Syair Pangeran Syarif. Malaysia: Universiti Kebangsaan Malaysia.

Wiranto. 1999. 'ARSITEKTUR VERNAKULAR INDONESIA Perannya Dalam Pengembangan Jati Diri'. DIMENSI (Jurnal Teknik Arsitektur) $27 \quad$ (2). https://doi.org/https://doi.org/10.9744/dimens i.27.2. 